\title{
Baixa resposta da vacinação intradérmica contra hepatite $B$ em pacientes incidentes em hemodiálise
}

\author{
Low response to intradermal hepatitis $B$ vaccination in incident \\ hemodialysis patients
}

\section{Authors}

Carlos Abaeté de los Santos ${ }^{1}$

Regina H Medeiros ${ }^{1}$ Ana Elizabeth PL Figueiredo $^{1}$

Carlos Eduardo Polide-Figueiredo ${ }^{1}$

Domingos Otávio d'Avila ${ }^{1}$

Jaqueline Antonio Pacheco ${ }^{1}$

Carlos Abaeté de los Santos ${ }^{1}$

${ }^{1}$ Faculdade de Medicina da Pontifícia Universidade Católica do Rio Grande do Sul (PUC/RS).
Submitted on: 29/07/2011 Accepted on: 02/08/2011

\footnotetext{
Correspondence to: Carlos Abaeté de los Santos Faculdade de Medicina da Pontifícia Universidade Católica do Rio Grande do Sul

Av. Ipiranga, 6.690

Porto Alegre (RS) - Brasil CEP: 90610-000

E-mail: abaete@pucrs.br
}

The authors report no conflict of interest.
Palavras-chave: Insuficiência renal crônica. Diálise renal. Vacinação. Vírus da hepatite B.

Keywords: Renal insufficiency, chronic. Renal dialysis. Vaccination. Hepatitis B virus.

\section{DeAr Editor,}

We thank Prof. Alavian for his interest in our paper. The preferential route for hepatitis $B(\mathrm{HB})$ vaccine administration remains controversial in hemodialysis (HD) patients. Our study aiming to compare intramuscular (IM) or intradermal (ID) inoculations was discontinued six months after starting, due to a Safety Monitoring Committee recommendation, since IM vaccination converted $62.3 \%$ of the patients, whereas the ID only $13.3 \%$. These results would not allow ethically crossing the groups as proposed. Besides, the aim was to include only naïve patients. However, of those eight patients who did not respond to ID vaccine, seven were submitted to IM injections: three achieved adequate antiHB levels and four did not. As emphasized in the text, one of the possible causes to the unresponsiveness was the presence of associated inflammation. ${ }^{1}$ The vaccine dose applied (in micrograms!) may also have been one of the reasons.

\section{References}

1. Medeiros RH, Figueiredo AE, Poli-deFigueiredo CE, dAvila DO, de los Santos CA. Low response to intradermal hepatitis $B$ vaccination in incident hemodialysis patients. J Bras Nefrol 2011;33:45-:49. 